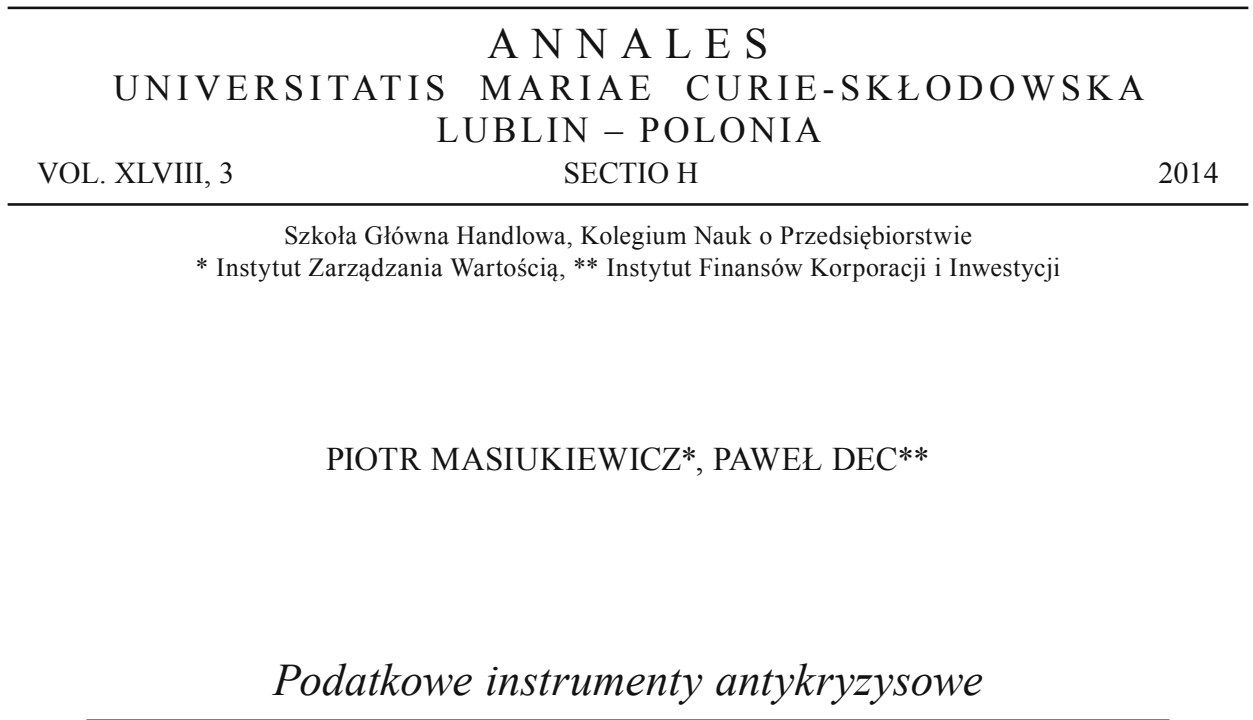

Tax anti-crisis tools

Słowa kluczowe: kryzys, podatki antykryzysowe, opłaty, regulacje

Key words: crisis, anti-crisis taxes, fees, regulations

\title{
Wstęp
}

Doświadczenia ostatniego kryzysu finansowego spowodowały powrót do stosowania specyficznego instrumentu zapobiegania kryzysom, mianowicie podatków antykryzysowych. Znowu rozwiązań szuka się dopiero wtedy, kiedy wystąpi sytuacja krytyczna. W Unii Europejskiej ogłoszono projekt dyrektywy w sprawie ogólnounijnego podatku od transakcji finansowych (FTT). Podatki antykryzysowe nie są nowym pomysłem; prace na ten temat opublikowali m.in. J.M. Keynes i J. Tobin, jednak instrument ten ciągle budzi kontrowersje. Można go analizować z wykorzystaniem różnych teorii: głównie finansów publicznych, interwencjonizmu państwowego, stabilności finansowej, regulatory capture, a także teorii bankowości. Trzeba jednak stwierdzić, iż nie ma dostępnych szerszych badań i publikacji na temat specjalnych podatków kryzysowych. Autorzy postarają się zatem wykazać, że instrument ten może zarówno skutecznie modyfikować zachowania korporacji, jak i zasilać fundusze naprawcze. 


\section{Teoretyczne aspekty podatków antykryzysowych}

Pod pojęciem podatku antykryzysowego (lub opłaty jako parapodatku) rozumiane jest specjalne obciążenie publicznoprawne, nakładane na firmy (szczególnie finansowe), w trakcie lub po kryzysie w celu jego dezaktywacji lub prewencji kryzysowej. Podatek bankowy natomiast to świadczenie pieniężne o charakterze przymusowym, bezzwrotne, pobierane przez państwo od instytucji finansowych i naliczane od wybranych pozycji pasywów albo aktywów ważonych ryzykiem, wynagrodzeń lub wartości transakcji finansowych [Schulmeister i inni, 2009].

Podatki (opłaty) o charakterze antykryzysowym mogą spełniać następujące funkcje:

- ograniczenie wolumenu określonego rodzaju transakcji finansowych, związane ze zmniejszeniem ryzyka systemowego,

- zasilenie budżetu państwa (w tym refinansowanie wydatków antykryzysowych),

- finansowanie specjalnego państwowego funduszu stabilizacyjnego (krajowego lub międzynarodowego),

- finansowanie specjalnego funduszu naprawczego dla banków lub przedsiębiorstw,

- ograniczenie wywozu kapitału z danego kraju lub napływu danej waluty do kraju,

- finansowanie zasiłków i rekwalifikacji bezrobotnych,

- ograniczenie nadmiernych wynagrodzeń $i$ in.

W praktyce gospodarczej przełomu XX i XXI wieku występowały różne typy podatków antykryzysowych (tabela 1).

Tabela 1. Typy podatków antykryzysowych

\begin{tabular}{|c|c|c|}
\hline Lp. & Typ podatku & Kraje występowania \\
\hline 1. & $\begin{array}{l}\text { Podatek od dochodów kapitałowych dla klientów } \\
\text { detalicznych }\end{array}$ & Część krajów OECD \\
\hline 2. & $\begin{array}{l}\text { Specjalny podatek od wysokich wynagrodzeń } \\
\text { - obciążający beneficjentów wynagrodzeń lub } \\
\text { podmioty gospodarcze wypłacające ponadnor- } \\
\text { matywne wynagrodzenia }\end{array}$ & $\begin{array}{l}\text { Islandia, Portugalia, Wielka Brytania (okresowo). } \\
\text { Niektóre kraje przygotowują wdrożenie }\end{array}$ \\
\hline 3. & $\begin{array}{l}\text { Jednorazowa opłata kryzysowa od podmiotów } \\
\text { gospodarczych lub osób fizycznych }\end{array}$ & Projekt ogłoszony na Cyprze \\
\hline 4. & $\begin{array}{l}\text { Podatek lub opłata od instytucji finansowych } \\
\text { (np. podatek bankowy) }\end{array}$ & $\begin{array}{l}\text { Stosuje } 15 \text { krajów UE. Projekt powszechnego } \\
\text { FTT w UE }\end{array}$ \\
\hline 5. & Podatek konsumpcyjny & Nieliczne kraje, np. Japonia \\
\hline 6. & Podatek socjalny & Francja (okresowo) \\
\hline 7. & Podatek minimum (fairness tax) & Projekt ogłoszony w Belgii \\
\hline
\end{tabular}

Źródło: opracowanie własne. 
W czasie kryzysów w latach osiemdziesiątych i dziewięćdziesiątych kilka krajów wprowadziło podatki od transakcji finansowych jako narzędzia antykryzysowe. Były to m.in. Szwecja [Schafer, 2012], Ekwador [Ostalecka, 2009] oraz Argentyna. Natomiast Japonia zastosowała zwiększenie stopy podatku konsumpcyjnego w trakcie kryzysu w latach dziewięćdziesiątych.

Doświadczenia dotyczące podatków antykryzysowych rodzą szereg fundamentalnych wątpliwości, takich jak pytanie o to, czy podnosić czy też obniżać podatki w czasie kryzysu; jakiego typu podatki antykryzysowe wprowadzać i na jakie cele je przeznaczać. Do rozstrzygnięcia jest też problem długości trwania obciążenia publicznoprawnego (jednorazowe, okresowe czy bezterminowe) oraz czy powinny one stanowić koszt uzyskania przychodu. Doświadczenia kryzysu subprime wskazują, że nie należałoby wprowadzać dodatkowych obciążeń publicznoprawnych w okresie kryzysu, a raczej gdy już poprawi się sytuacja gospodarcza [Dec, Masiukiewicz, 2013]. Formułowane są też różne poglądy co do korzyści i zagrożeń poszczególnych modeli podatku bankowego (FTT, FAT, FSC) [Schafer, 2012; Dec, Masiukiewicz, 2011; Schulmeister i inni, 2009]. Istnieje też kwestia międzynarodowej unifikacji podatków antykryzysowych oraz możliwości ustanowienia powszechnego podatku unijnego FTT.

W niektórych krajach w czasie ostatniego kryzysu finansowego stosowano odwrotną politykę podatkową, tj. obniżano podatki (np. w czasie kryzysu subprime w USA, Irlandii i na Węgrzech). Także w Polsce w latach dziewięćdziesiątych w warunkach kryzysu gospodarczego banki spółdzielcze uzyskiwały przez kilka lat zwolnienie od podatku dochodowego pod warunkiem przeznaczenia całości zysku na fundusze własne [Dec, Masiukiewicz, 2013].

\section{Wybrane przykłady wdrażania podatków antykryzysowych}

\subsection{Wielka Brytania}

W czasie ostatniego kryzysu gospodarczego koalicja konserwatystów i liberałów w Wielkiej Brytanii negocjowała z bankami przyjęcie procedury, która zmuszałaby je do ujawniania najwyższych zarobków oraz premii pracowników. Rząd G. Browna w 2009 r. nałożył na banki jednorazowy 50-procentowy podatek od premii bankowych wyższych niż 25 tys. GBP [Schaefer-Munoz, MacDonald, 2009; Banki..., 2011]'. Dzięki temu uzyskano wpływy na poziomie 2,3 miliarda funtów ${ }^{2}$.

\footnotetext{
${ }^{1}$ W Irlandii były nawet pomysły ustalenia stawki 90\% od premii bankowców, zob. [Rząd, 2010].

2 W Polsce w latach dziewięćdziesiątych stosowano podatek od ponadnormatywnych wypłat wynagrodzeń obciążający firmy. Był on bardzo restrykcyjny, np. przekroczenie o więcej niż 5\% wzrostu funduszu płac skutkowało 500-procentowym podatkiem; można go uznać za instrument antykryzysowy, zob. [Owsiak, 2005].
} 


\subsection{Francja}

W 2009 r. francuski rząd podjął decyzję o opodatkowaniu jednorazową stawką $50 \%$ premii (powyżej 27,5 tysiąca euro) wypłacanych menedżerom banków i filii banków zagranicznych działających we Francji [France Plans..., 2009]. Miał on przynieść budżetowi Francji $360 \mathrm{mln}$ euro [Francja..., 2010]. Jako uzasadnienie dla tego podatku podano chęć udzielenia wcześniejszej pomocy publicznej bankom w trakcie kryzysu (m.in. Societe Generale, BNP Paribas, Credit Agricole). Szacowano, że obejmie on około 2,5 tys. pracowników. W grudniu 2013 r. we Francji zatwierdzono 75-procentową stawkę podatkową dla milionerów. Według założeń ustawy wszyscy otrzymujący wynagrodzenia powyżej 1 miliona euro płaciliby podatek 50-procentowy, a łącznie $\mathrm{z}$ dodatkowymi obciążeniami podatkowymi i socjalnymi jego rzeczywista stawka wynosiłaby właśnie 75\% [France’s Hollande..., 2013].

\subsection{Islandia}

W 2012 roku na Islandii wprowadzono specjalny podatek dla sektora finansowego - od wynagrodzeń3 ${ }^{3}$ Dotyczy on banków, kas komercyjnych, ubezpieczycieli, domów maklerskich, funduszy inwestycyjnych. Obciąża zarówno banki krajowe, jak i ich oddziały zagraniczne i oddziały banków zagranicznych na Islandii. Jego podstawą jest każdy rodzaj wynagrodzenia, w tym płace, dodatki do wynagrodzenia, pożyczki dla pracowników, darowizny, odszkodowania oraz inne korzyści. Wyłączone są natomiast renty, emerytury, a także zasiłki macierzyńskie. Opodatkowanie odszkodowań i pożyczek należy uznać za szczególnie restrykcyjne. Stawki zostały określone progresywnie i wynoszą $5,45 \%$ dla podstawy opodatkowania mniejszej niż miliard koron islandzkich, a $6,00 \%$ dla podstawy większej. Podatek ten można zaliczyć do kosztów uzyskania przychodów, a wpływy z niego zasilają budżet państwa.

\subsection{Portugalia}

Nadzwyczajny podatek kryzysowy od płac wprowadzono w Portugalii. Wszystkich pracowników osiągających dochody wyższe od płacy minimalnej obowiązuje 50-procentowy podatek od czternastej pensji (wprowadzony w 2011 roku) [Millet, Toussaint, 2012]. Ma raczej symboliczny charakter zarówno co do wpływu na politykę wynagrodzeń, jak i na dochody budżetu państwa. Jest to raczej działanie mające wykazać Komisji Europejskiej, iż rząd podejmuje jakiekolwiek kroki zaradcze w sprawie kryzysu.

\footnotetext{
3 Wprowadzony na mocy ustawy nr 165/2011.
} 


\section{Podatki antykryzysowe na szczeblu centralnym w Unii Europejskiej}

Po kryzysie subprime podatki (FAT) lub opłaty antykryzysowe (bank levy) wprowadziło w UE już 15 krajów (tabela 2), a trzy wdrożyły także podatek specjalny od nadmiernie wysokich wynagrodzeń [Masiukiewicz, Dec, 2012]. Podatek od transakcji finansowych (w różnej formie) zastosowano też w niektórych krajach pozaeuropejskich (Brazylia, Indie, Korea Południowa i Tajlandia) [Płókarz, 2013, s. 346].

Tabela 2. Nowe podatki antykryzysowe nałożone na instytucje finansowe w UE

\begin{tabular}{|c|l|c|}
\hline Lp. & Typ podatku (opłaty) dla instytucji finansowych & $\begin{array}{c}\text { Liczba krajów, które wpro- } \\
\text { wadziły dany instrument }\end{array}$ \\
\hline 1 & Podatek FAT dla instytucji finansowych* & 9 \\
2 & Podatek FAT dla dużych banków & 2 \\
3 & Opłata bankowa & 4 \\
4 & Specjalny podatek bankowy od nadmiernie wyso- & $3^{* *}$ \\
& kich wynagrodzeń menedżerów wysokiego szczebla & 15 \\
\hline & Razem & \\
\hline
\end{tabular}

"W niektórych krajach dotyczy banków oraz niektórych innych instytucji finansowych, np. ubezpieczeniowych.

"* Podatek dodatkowy w krajach, które wprowadziły inne podatki bankowe.

Źródło: opracowanie własne na podstawie [Dec, Masiukiewicz, 2013].

System opodatkowania instytucji finansowych w UE jest zróżnicowany. Generalnie transakcji (usług) finansowych nie obejmuje podatek VAT. Transakcje giełdowe papierami wartościowymi są natomiast $\mathrm{w}$ wielu krajach obciążone podatkiem od czynności cywilnoprawnych lub opłatą skarbową (zwykle 0,5-1\% podstawy opodatkowania). Tak zwany podatek kapitałowy (w tym od odsetek z tytułu lokat bankowych) nałożony na osoby fizyczne (płatnikiem są instytucje finansowe) występuje w części krajów UE. Jego ogólne zasady i wymianę informacji wewnątrz Unii reguluje specjalna dyrektywa [Council Directive..., 2003]. Podatek ten wpływa negatywnie na wzrost oszczędności, dlatego wydaje się, że podczas kryzysów finansowych jego pobór powinien być zawieszany. Obecnie prowadzone są prace nad wprowadzeniem ogólnounijnego podatku od transakcji finansowych (FTT), który obok funkcji fiskalnych miałby także prowadzić do stabilizacji finansowej [Dalton, 2010]. Wdrożenie unijnej dyrektywy w sprawie FTT oznaczałaby w wielu krajach występowanie dwóch podatków bankowych (krajowego i unijnego), co pogorszyłoby konkurencyjność banków i zapewne spowodowałoby wzrost ceny kredytów. Nałożenie specjalnego podatku na sektor finansowy jest uzasadniane m.in. potrzebą zgromadzenia dodatkowych środków publicznych na ewentualne wsparcie kryzysowe oraz poprawę stabilności finansowej oraz ograniczenie transakcji o wysokim ryzyku. 
W UE w ostatnich latach trwały prace nad obniżeniem wysokości premii dla bankowców [EU agrees..., 2013]. Nowe regulacje dla sektora bankowego przewidziane w dyrektywie CRD IV (miały obowiązywać od początku 2014 r.) uwzględniają restrykcje w zakresie wynagrodzeń tej grupy zawodowej. Ma to sprawić, aby systemy wynagradzania nie zachęcały do podejmowania nadmiernego ryzyka. Według ustaleń wysokość premii dla bankowców nie może przekraczać wysokości stałej pensji, a w sytuacji, kiedy większość udziałowców banku zgodzi się na wyższą premię, to nie może ona przekroczyć dwukrotności pensji. Nowe przepisy obejmą wszystkie banki działające w UE oraz te prowadzące działalność poza Unią. Kwestia premii były przedmiotem ostrych sporów w trakcie negocjacji, a największe zastrzeżenia zgłaszała Wielka Brytania - nowe regulacji mogą zaszkodzić londyńskiemu City. W kwietniu 2013 r. nowa dyrektywa została przyjęta przez Parlament Europejski [EU Bank..., 2013].

\section{Podatki dla wielkich korporacji}

Zalety dużych podmiotów wymieniane w publikacjach lat dziewięćdziesiątych to między innymi odporność na kryzysy, a także procesy konsolidacji, efekt skali, standaryzacja i umiędzynarodowienie produktów, większy potencjał i nakłady na innowacje, zmiany jakościowe kapitału ludzkiego oraz dostęp klienta do oferty w wielu miejscach świata. Konsolidację, globalizację i standaryzację uznawano za kierunek nowoczesnych przemian w biznesie, $w$ tym na rynkach finansowych.

Wielkie korporacje w ostatnim 20-leciu weszły z własną ofertą produktową na rynek finansowy. Sieci handlowe oferują m.in. pożyczki, karty kredytowe, usługi pieniężne. Koncerny samochodowe prowadzą własne banki i pośrednictwo ubezpieczeniowe (np. Toyota Bank Polska). Korporacje są także ważnymi graczami na rynku kapitałowym. W konsekwencji mają zatem swój udział w kreowaniu ryzyka finansowego, w tym systemowego [Masiukiewicz, 2010].

Kryzys subprime obnażył wiele słabości w funkcjonowaniu wielkich korporacji na rynku. Należy też pamiętać, że wielkość aktywów niektórych podmiotów przekraczała PKB kraju - siedziby, tworząc nowe ryzyko [Masiukiewicz, 2012]. Spośród wad i dysfunkcji w działaniu dużych podmiotów biznesowych wymienia się między innymi takie jak:

- ograniczanie niezależności konsumentów i niszczenie konkurencji małych firm,

- zróżnicowana efektywność, niekiedy nieodbiegająca od małych przedsiębiorstw oraz w niektórych przypadkach kreatywna księgowość (np. Enron w USA),

- dysfunkcje i patologie organizacji, w tym generowanie dodatkowych kosztów, nieracjonalność niektórych decyzji,

- szumy informacyjne i niska etyka marketingu,

- dysfunkcjonalne systemy motywacji menedżerów wysokiego szczebla,

- niska etyka podatkowa (w niektórych przypadkach), 
- niepoddawanie się procedurom upadłości według zasady: zbyt ważny i zbyt duży, by upaść,

- ułomności nadzoru korporacyjnego i alienacja zarządzania od własności.

Firma Deloitte w 2013 r. przeprowadziła analizę 500 największych firm działających w Europie Środkowo-Wschodniej. Ponad 40\% badanych podmiotów z roku na rok miało gorsze wyniki finansowe i wykazywało mniejszą odporność na kryzys [Masiukiewicz, 2012; Duże firmy..., 2013]. Na fali krytyki wielkich korporacji w sferze realnej formułowane są ostatnio postulaty ich większej regulacji i kontroli. Instrumenty fiskalne ograniczania ryzyka systemowego wielkich korporacji przemysłowych i handlowych mogą być następujące:

- opłaty komunalne (regionalne),

- podatek od aktywów lub sprzedaży,

- podatek od nadmiernych wynagrodzeń,

- opłata na fundusz wypłat wynagrodzeń w upadłych firmach,

- podatek minimum lub opłata stabilizacyjna na krajowy fundusz restrukturyzacji i naprawy przedsiębiorstw.

Ustawa Dodda-Franka w USA wprowadziła przepis upoważniający FED do wpisania na listę dużych instytucji - strategicznych dla bezpieczeństwa finansowego - każdej firmy, którą uzna za ważną dla tego bezpieczeństwa. Przedsiębiorstwa funkcjonujące w sektorze usług w czasie ostatniego kryzysu na Węgrzech zostały obciążone dodatkowym podatkiem dochodowym - m.in. w celu ratowania budżetu w okresie kryzysu. Z kolei drobni przedsiębiorcy (obroty do $500 \mathrm{mln}$ forintów) w tym okresie płacą obniżony do 10\% podatek dochodowy [Gadomski, 2013, s. 14]. W Belgii tysiąc przedsiębiorstw o największych zyskach w 2010 r. zapłaciło efektywny podatek dochodowy w wysokości 5,73\%, chociaż nominalna stopa podatkowa wynosiła w tym okresie 33,99\% [Millet, Toussaint, 2012, s. 127]. Pod wpływem krytyki społecznej rząd Belgii rozważa wprowadzenie specjalnego podatku dla wielkich korporacji tzw. podatku uczciwości, zwanego też minimum (fairness tax lub minimum tax) [Podatki..., 2013].

Otwarte pozostają pytania o to, czy i jak szeroko powinna być regulowana działalność wielkich korporacji oraz jak ograniczać dysfunkcjonalne efekty ich działalności poprzez system podatkowy. Można też przewidywać stopniowe wprowadzanie w niedalekiej przyszłości specjalnych podatków dla dużych korporacji.

\section{Zakończenie}

Kryzys subprime ujawnił nieznane dotąd patologie i dysfunkcje w działalności korporacji finansowych, a także przemysłowych; były one kreatorami kryzysu. Współcześnie poszukuje się instrumentów antykryzysowych. Podatki z pewnością stanowią lepszy instrument ograniczania ryzyka kryzysu niż normy administracyjne. Nie są jednak jedynym panaceum i powinny być komplementarne wobec innych regulacji 
systemowych. Wprowadzanie podatków antykryzysowych powinno mieć miejsce w czasie prosperity w gospodarce, a w okresie kryzysu powinny być one zawieszane - by ograniczyć negatywny efekt cykliczności. Właściwe wydaje się stosowanie elastycznych modeli podatkowych (ulgi, moratorium itp.), ale też dotkliwych sankcji za arbitraż podatkowy, zawyżanie kosztów i inne. Problemem jest także kompatybilność regulacji oraz podatków wobec celów antykryzysowych polityki państwa.

Zaawansowane prace w UE w kwestii FTT pozwalają stwierdzić, że z pewnością zostanie on wprowadzony w 2014 r. Dla wielu krajów będzie to oznaczać funkcjonowanie dwóch specjalnych podatków (opłat) bankowych, a w Polsce nawet trzech. Jeżeli podatek od transakcji finansowych nie zostanie zastosowany w skali globalnej, to europejskie banki znajdą się w gorszej pozycji konkurencyjnej lub będą przeprowadzać operacje na innych kontynentach. Złym rozwiązaniem jest umieszczanie wpływów z podatków antykryzysowych w budżetach ogólnych na cele bieżące; środki te mogą natomiast pracować dla budżetu państwa w charakterze lokat w obligacje i bonów skarbowych.

\section{Bibliografia}

1. Banki w Wielkiej Brytanii zapłaca wyższy podatek, www.forbes.pl (dostęp: 08.02.2011).

2. Council Directive no 2003/48/EC of 3 June 2003 on taxation of savings income in the form of interest payments, OJEU, no L 157/38, z dn. 26.06.2003.

3. Dalton M., UE Plans Bank Levy to Support Crisis Funds, "The Wall Street Journal", 27.05.2010.

4. Dec P., Masiukiewicz P., Banking Tax in European Union, "Annals of Dunarea de Jos University of Galati, Fascicle I. Economics and Applied Informatics” 2011, no. 2.

5. Dec P., Masiukiewicz P., Podatek bankowy, C.H. Beck, Warszawa 2013.

6. Duże firmy już nie sq odporne na kryzys, www.podatki.biz (dostęp: 29.08.2013).

7. EU agrees to cap bankers' bonuses, www.ft.com (dostęp: 28.02.2013).

8. EU Bank Capital Requirements Regulation and Directive, www.europarl.europa.eu (dostęp: 16.04.2013).

9. Financial Sector Taxation, Commission Staff Working Document, no. 1166, European Commission, Brussels 2010.

10. France Plans to Tax Bankers' Bonuses at 50\%, www.wsj.com (dostęp: 17.12.2009).

11. France's Hollande Gets Court Approval for 75\% Millionaire Tax, www.bloomberg.com, 29.12.2013.

12. Francja: podatek od premii bankowców, www.rp.pl (dostęp 13.01.2010).

13. Gadomski W., Jak Victor Orbán kupuje zaufanie Wegrów, „Gazeta Wyborcza”, 19.09.2013.

14. Informacja dotyczaca działań antykryzysowych podejmowanych $w$ wybranych krajach świata, Ministerstwo Gospodarki, Warszawa, lipiec 2009, www.mg.gov.pl (dostęp: 15.09.2013).

15. Keynes J.M., The General Theory of Employment, Interest and Money, Harcourt Brace \& World, New York 1936.

16. Masciandaro D., Passarelli F., The Financial Transaction Tax: a Political Economy View, "Intereconomics" 2012, no. 2.

17. Masiukiewicz P., Ryzyko dużych banków - perspektywa Polski, CeDeWu.pl, Warszawa 2012.

18. Masiukiewicz P., System motywacji top-menedżerów jako akcelerator kryzysu, „Ekonomika i Organizacja Przedsiębiorstwa” 2010, nr 10. 
19. Masiukiewicz P., Dec P., Special Taxes in Banking, "Perspectives of Business, Innovations, Economics Journal" 2012, no. 11.

20. Millet D., Toussaint E., Kryzys zadtużenia i jak z niego wyjść, Instytut Wydawniczy „Książka i Prasa", Warszawa 2012.

21. Ostalecka A., Kryzysy bankowe i metody ich przezwyciężania, Difin, Warszawa 2009.

22. Owsiak S., Finanse publiczne. Teoria i praktyka, Wydawnictwo Naukowe PWN, Warszawa 2005.

23. Płókarz R., Globalne rynki finansowe, Wydawnictwo Naukowe PWN, Warszawa 2013.

24. Podatki na świecie: Belgia ma sposób na wielkie korporacje, www.podatki.biz (dostęp: 30.08.2013).

25. Rząd Irlandii chce 90 proc. podatku od premii bankowców, www.pb.pl (dostęp: 10.12.2010).

26. Schäfer D., Financial Transaction Tax Contributes to More Sustainability in Financial Markets, "Intereconomics" 2012, no. 2.

27. Schaefer-Muñoz S., MacDonald A., Banks' Bonuses Hit by 50\% Levy in UK Budget, "The Wall Street Journal", 10.12.2009.

28. Schulmeister S., Schratzenstaller M., Picek O., A General Financial Transaction Tax - Motives, Revenues, Feasibility and Effects, Österreichisches Institut für Wirtschaftsforschung, "Working Paper", Vienna 2009.

\section{Tax anti-crisis tools}

Both the European Union and other countries analysed and searched effective instruments against the crisis. Currently, it takes not only a European debate on tax or bank charges. They have also taken action. Indeed, the EU published a draft directive on EU tax on financial transactions, as well as the adopted solutions that reduce high bonuses in the banking sector. However, in the countries considered there are (or have once been introduced) special taxes for large corporations and taxes on high salaries. Bank taxes can be an effective anti-crisis tool that will probably come permanently to the tax system of the European Union. This cannot, however, be the sole anti-crisis instrument, so it is necessary to analyse and search for additional and complementary of tools against the crisis. 